\title{
Evaluating Index System of Enterprise Informatization and Index Calculation Method
}

\author{
Fan Tao \\ Jilin Institute of Chemical InDustry \\ Jilin City,Jilin Province, China \\ E-mail: Fantaoya1130@163.com
}

\begin{abstract}
This paper proposes a more scientific and complete evaluation index system of enterprise information. This paper focuses on the research on enterprise informatization evaluation method, constructs the comprehensive index model , and uses AHP to determine the index weight and fuzzy membership function and expert grading index dimensionless treatment, provides the basis for scientific evaluation of the level of enterprise informatization and correct guidance to enterprise information construction.
\end{abstract}

Keywords-informatization of enterprises, index system, index calculating, evaluation

\section{EVALUATING INDEX SYSTEM OF ENTERPRISE INFORMATIZATION AND INDEX CALCULATION}

\section{A. Constitution of the Index System}

Definition and content of enterprise informatization as well as reference to the "The Construction Framework of National Informatization Indices" released by MII jointly constitute the index system of enterprise informatization. The index system operates in the way of hierarchical evaluation. The first level includes 4 indicators which are the four major attribute factors in the informatization system of enterprises; Level two includes 17 indicators which respectively observe the attribute factors. Check table 1 for details of index system:

TABLE I. INDEX SYSTEM OF ENTERPRISE INFORMATIZATION

\begin{tabular}{|c|c|c|c|c|}
\hline $\begin{array}{l}\text { First level } \\
\text { indicator }\end{array}$ & Weight & $\begin{array}{c}\text { Indicator of } \\
\text { level two }\end{array}$ & Weight & $\begin{array}{c}\text { Indicator of level } \\
\text { three }\end{array}$ \\
\hline & & \multirow{4}{*}{$\begin{array}{l}\text { Construction } \\
\text { of } \\
\text { informatized } \\
\text { organization }\end{array}$} & & $\begin{array}{l}\mathrm{A}_{1} \text { Arrangement } \\
\text { and location of } \\
\text { information } \\
\text { department }\end{array}$ \\
\hline & & & & $\begin{array}{c}\text { A2 Team } \\
\text { construction } \\
\text { of informatization }\end{array}$ \\
\hline & & & & $\begin{array}{l}\mathrm{A}_{3} \text { Evaluation on } \\
\text { human resource }\end{array}$ \\
\hline & & & & $\begin{array}{c}\mathrm{A}_{4} \text { Economical } \\
\text { planning }\end{array}$ \\
\hline
\end{tabular}

\begin{tabular}{|c|c|c|}
\hline \multirow{9}{*}{$\begin{array}{l}\text { Developing } \\
\text { index of } \\
\text { enterprise } \\
\text { informa } \\
\text { tization }\end{array}$} & & of informatization \\
\hline & \multirow{5}{*}{\begin{tabular}{l}
\multicolumn{1}{c}{ Basic } \\
facilities of \\
information
\end{tabular}} & $\begin{array}{c}\mathrm{A}_{5} \text { Equipped degree } \\
\text { of } \\
\text { information } \\
\text { equipment } \\
\text { and software }\end{array}$ \\
\hline & & $\begin{array}{c}\mathrm{A}_{6} \text { Owning } \\
\text { proportion of } \\
\text { telephone each } 100 \\
\text { person }\end{array}$ \\
\hline & & $\begin{array}{c}\mathrm{A}_{7} \text { Owning } \\
\text { proportion of } \\
\text { computer each } 100 \\
\text { person }\end{array}$ \\
\hline & & $\begin{array}{c}\mathrm{A}_{8} \text { Building level } \\
\text { of enterprise } \\
\text { network } \\
\text { and website }\end{array}$ \\
\hline & & $\begin{array}{c}\mathrm{A}_{9} \text { Construction } \\
\text { level of } \\
\text { Information } \\
\text { security technology }\end{array}$ \\
\hline & \multirow{3}{*}{$\begin{array}{l}\text { Information } \\
\text { resource }\end{array}$} & $\begin{array}{c}\mathrm{A}_{10} \text { Construction } \\
\text { size } \\
\text { and application } \\
\text { level } \\
\text { of database }\end{array}$ \\
\hline & & $\begin{array}{c}\mathrm{A}_{11} \text { Building level } \\
\text { of database and } \\
\text { mining } \\
\text { depth of data }\end{array}$ \\
\hline & & $\begin{array}{c}\mathrm{A}_{12} \text { Management } \\
\text { standardization } \\
\text { and management } \\
\text { mode reform of } \\
\text { enterprise }\end{array}$ \\
\hline
\end{tabular}




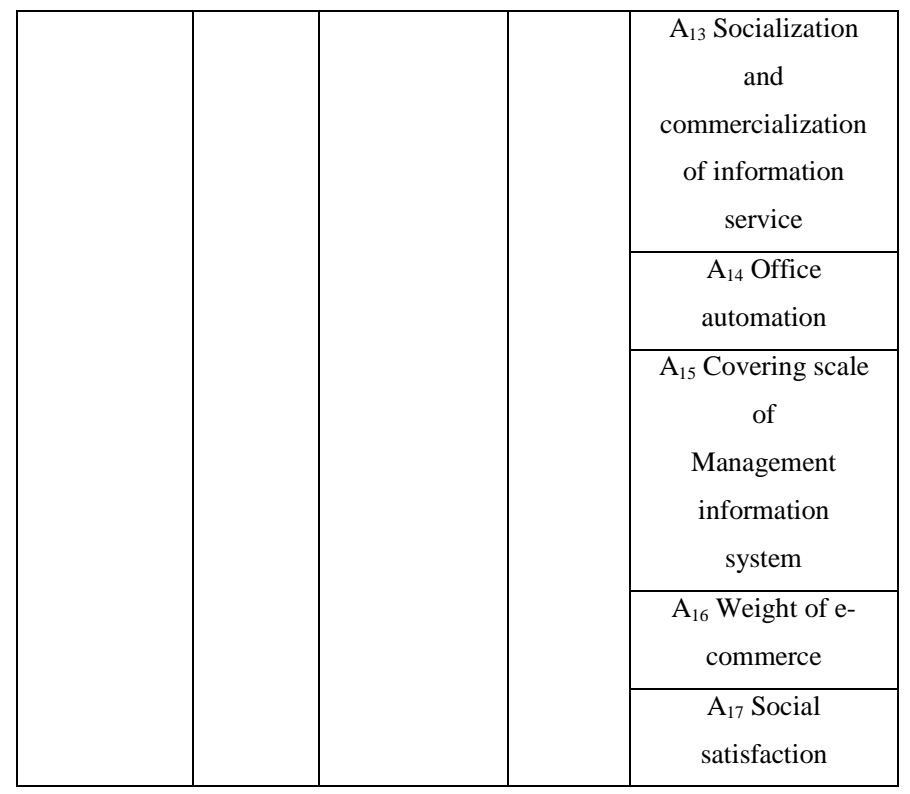

\section{B. Instruction on the Index and Index Calculating}

- Organization of Information Department

Expert scoring is conducted in the quantitative way of qualitative index. 2 points for each condition covered, and the total is 9: the establishment of the "Enterprise Informatization Commission" or "Information Center" and other organizations; set up CIO; enterprise leadership's attention and CEO served in the "Enterprise Informatization Commission" or "Information Center"; IT department set up in the commission; IT department and other departments at the same level.

- Informatization construction evaluation staff amount of IT business section+number of technology developer/total number of enterprise staff $\times 100 \%$

- evaluation enterprise: $\mathrm{A} 3=\frac{1}{4} \sum_{i=1}^{4} \mathrm{a} 3 \mathrm{i}(\mathrm{i}=1,2,3,4)$

- Covering rate of informatization training of staff $=$ annual number of staff who receive the informatization training/total number of enterprise's staff $\times 100 \%$

- Proportion of undergraduates and uppers in the enterprise $=$

Total number of undergraduates, postgraduates and doctors in the enterprise/Total number of enterprise's staff

$$
\times 100 \%
$$

- Proportion of full-time information technician $=$ Number of full-time information technician/Total number of enterprise's staff
- $\quad \times 100 \%$ enterprise $=$

Number of people involving in research and developing/Total number of enterprise's staff

$\times 100 \%$

- Economic informatization planning

IT product renews rapidly. It aims at the progressiveness of informatization rather than blindly encourages deficit spending. Therefore, although the information system needs a certain degree of advancement, it should depends on the given enterprise's self-conditions, demands and capacity, pursuing the higher cost performance and avoiding the unprofitable investment. The economical index of informatization planning essentially is to reflect the proper degree of informatization. The index uses quantitative processing method of qualitative index to conduct expert grading.

- Equipped Level of Information equipment and Software appliance:

\section{: $\mathrm{ZBL}=\mathrm{C}_{\mathrm{T}} / \mathrm{C}_{\mathrm{TZ}} \times 100 \%$}

Among the equation, the ZBL represents the equipped proportion of information equipment and software appliance.

$\mathrm{C}_{\mathrm{T}}$

The total investment cost on information equipments and softwares including: cost for purchasing telephone, fax machine, computer and peripheral equipment, construction fee of enterprise's intraner and extraner, investment cost of construction of the internet and the spending on purchasing information software, etc.

\section{$\mathrm{C}_{\mathrm{TZ}}-$ Total investment in fixed assets.}

Note: To large and medium-size enterprises, the index can be subdivided. At the basis of the index, equipped proportion of single information equipment and software appliance is added as a complement. This added index is the ratio between the total investment cost of a given information equipment and software appliance and the total investment cost of all information equipments and software appliances.

- Owning rate of telephone per 100 person =

Total number of telephone installed in the enterprise/Total number of staff

$\times 100 \%$

- Owning rate of computer per 100 person =

Total number of computer that can operate normally/Total number of staff

$\times 100 \%$

- Building level of enterprise's network and website =

$\mathrm{a}_{8}=\frac{1}{3} \sum_{\mathrm{i}=1}^{3} \mathrm{C}_{8 \mathrm{i}}(\mathrm{i}=1,2,3)$

- Network performance, this index is able to give expert scores by the quantitative method of 
qualitative index, and the scoring principles as follows:

\begin{tabular}{|l|c|c|c|c|}
\hline $\begin{array}{r}\text { Netw } \\
\text { ork and } \\
\text { bandwidt } \\
\mathrm{h}\end{array}$ & $\mathrm{S} \leq 512 \mathrm{~K}$ & $\begin{array}{c}512 \mathrm{~K} \\
<\mathrm{S} \leq 2 \mathrm{M} \\
2 \mathrm{M}<\mathrm{S} \\
\leq 10 \mathrm{M}\end{array}$ & $\begin{array}{l}10 \mathrm{M} \\
<\mathrm{S} \leq 100 \\
\mathrm{M}\end{array}$ & \multicolumn{2}{|c|}{$\mathrm{S}>100$} \\
\hline Score & 1 & 3 & 7 & 9 \\
\hline
\end{tabular}

- $\quad$ Service object of the network. Full mark is 9, and 2 points for each following content that is covered. The service object list: employees, decision makers, clients, suppliers and other partners.

- The function of network service. Full mark is 9, and 1 points for each following content that is covered. Service function list: information publishing, online procurement, online sales, online self-service, authentication of employee's identity, mobile commerce, automatic transmission of messages, business alarm, etc.

- Information security technology. This index is able to give expert scores by the quantitative method of qualitative index. The full mark is 9 points. 2 points for each of the following actions that is adopted. Security measures includes: Local real-time, regular backups; remote real-time, scheduled backups; install a firewall and anti-virus software and timely upgrades; no accident within a year in e-commerce; good operation of automatically restore system.

- The construction scale of database. Construction scale of database includes: suppliers, purchasing and business processing, manufacturing, marketing, distribution and heap retailers, customer relations, finance, human resources, e-commerce. 1 point for each covered out of the total 9 .

- Capability of building date warehouse and mining depth of data. Date warehouse refers that date is cleaned, filtered and synthesized on the basis of database operating system so as to form a OLAP concerning the subject. Decision-makers can use the OLAP to analyze and synthesize the subjects that they are interested in, making the decision more scientific, precise and timely. Data mining is that data cubes in the data warehouse form for discovery of knowledge. Usually, data is processed by means of classification, clustering, association rules analysis and data generalization. Data mining aims to enable decisionmakers to obtain useful and novel knowledge in the masses of data, thus improving the scientific decisionmaking. This index mainly describes the level of enterprise' s comprehensive utilization about data and gives expert scores through the quantitative method of qualitative index.

- Standardization of enterprise management and management mode reform

- $\quad=$ number of management dep after informatization number of before informatization

- $\quad=$ number of functional dep after informatization number of before informatization
- = average number of every section after informatization - average number of before informatization

- = management levels after informatization management levels Before informatization

About the four indicators above, if a12 $\mathrm{i} \geq 0$, no score; if a12 $\mathrm{i}<0,2$ points are attached of total 9 . $(\mathrm{i}=1,2,3,4)$

- Socialization and commercialization of information service:

There into, Fs - - production of IT department's external service service

Fp - - production of IT department's internal

Fw_- value of information service the enterprise received from of science.

Professional technical company and academy

- Office automation. This index is able to give expert scores by the quantitative method of qualitative index. 2 points for each feature following that is covered and effective, 1 point for each covered but ineffective. And the full mark is 9. Functions of OA: data processing, document management, information and communication, schedule management and decision support.

- Covering scale of information system of enterprise management

Calculating method: had any item been included, one point for each out of 9 .

Coverage: Financial Management, Supply Chain Management (CSM), Customer Relationship Management (CRM), manufacturing management, material management, labor and personnel management, operating management, management of equipment' s energy, e-commerce.

- Proportion of e-commerce:

=Enterprise's annual sales volume of e-commerce/ Total annual sales volume

$\times 100 \%$

Social satisfaction.Questionnaire can be designed to conduct a survey, in which the results can be divided into 5 levels: "satisfied", "less satisfied", "acceptable", "not bad", "bad". And they respectively are marked by $9,7,5,3,1$. Moreover, the result also can be marked with $8,6,4,2$ when the actual situation sits between the five levels. Then treat it from the forward direction with dimensionless processing.

\section{COMPREHENSIVE EVALUATION OF ENTERPRISE'S INFORMATIZATION LEVEL}

\section{A. Confirmation of Index Weight}

Determine the weight of each index using the analytic hierarchy process (AHP): at each level, compare each of two elements according to the a certain regulation. And experts compare each of the two indices with the method of 1-9 scales to work out a histogram of comparative results--$\mathrm{B}=(\mathrm{bij})$. By calculating the maximum eigenvalue and 
corresponding eigenvector, we can work out the weight of each element comparing to its regulation.

\section{B. Dimensionless processing to index}

Since there are forward indicator, reverse indicator and moderate indicator in the index system and no quantitative boundaries between their badness and goodness, so it is feasible to use fuzzy quantification, namely fuzzy membership function, to dimensionlessly process every index.

Determine the upper and lower limits of each evaluation index

Xim and zero are respectively regarded as the maximum and minimum value in the enterprise.

As to reverse indicator, Xim is also the minimum value in enterprise. Confirm the threshold according to the given index's features and informatizational requirements. Any index that exceeds the threshold will be excluded.

Moderate index, determine the moderate value $\mathrm{XiO}$ according to the features and informatizational requirements of the given index. The $\mathrm{XiO}$ is also the best value of informatization. Respectively determine the upper and lower thresholds of the index, Xim and Xin, by centering on the $\mathrm{Xi0}$.

Confirm the type of index's fuzzy membership function.

In the fuzzy mathematics, use a real number ranging from 0 to 1 to represent the degree of something belonging to a certain standard. "0" means completely non-subordination while "1" means full membership. Fuzzy membership function is used to describe the gradual process. To calculate simply, choose linear fuzzy membership function to be quantified, as follows:

For the forward indicator, using half-elevated trapezoidal fuzzy membership function to quantify:

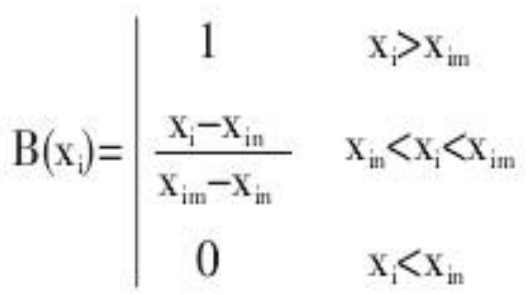

For the reverse indicator, using half-descended trapezoidal fuzzy membership function to quantify:

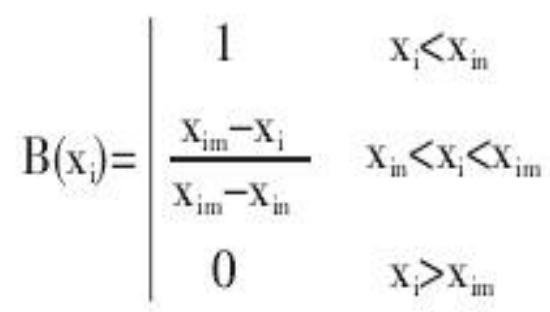

For the moderate indicator, using half-elevated trapezoidal fuzzy membership function to quantify:

$$
\mathrm{B}\left(\mathrm{x}_{\mathrm{i}}\right)=\mid \begin{array}{cc}
\frac{2\left(\mathrm{x}_{\mathrm{i}}-\mathrm{x}_{\text {in }}\right)}{\mathrm{x}_{\text {im }}-\mathrm{x}_{\text {in }}} & \mathrm{x}_{\text {in }} \mathrm{x}_{\mathrm{i}}<\mathrm{x}_{\mathrm{ib}} \\
\frac{2\left(\mathrm{x}_{\text {im }}-\mathrm{x}_{\mathrm{i}}\right)}{\mathrm{x}_{\text {im }}-\mathrm{x}_{\text {in }}} & \mathrm{x}_{\mathrm{io}}<\mathrm{x}_{\mathrm{i}}<\mathrm{x}_{\text {im }} \\
0 & \mathrm{x}_{\mathrm{i}}<\mathrm{x}_{\text {in }} \text { 或 } \mathrm{x}_{\mathrm{i}}>\mathrm{x}_{\text {im }}
\end{array}
$$

\section{CONCLUSION}

In recent years, "driving industrialization with informatization", " promoting the integration of informatization and industrialization" and other major national policy are more and more paid attention to and implement, but, due to the lack of funds, talent, technology, policy, and confusion of consciousness, error positioning, etc., our enterprise informatization development lagged, which seriously influenced the survival ability and the overall competitiveness of enterprises in our country, consequently, also seriously affect our productivity and economic growth. Therefore, it is very important. to evaluate the enterprise informatization level through scientific means.

\section{REFERENCES}

[1] Bing Liang. The Basic Theory and Evaluation methods of enterprise informatization [M]. Beijing: science press, 2008.

[2]Tang Xiaowo, Hou Lun and others. Discussion on enterprise informatization and index system [J]. University of Electronic Science and technology Journal (version of social science), 2010, (6).

[3] Zhang Yonggang. Research on the Difficulties and Policies of enterprise's informatization construction [J]. Journal of Chongqing Institute of Technology, 2011,(5)

[4]Richard. T. Due. The Value of Information. Information Systems Management, 1996,(3).

[5]LP.Rai.k.lal.Indicators of the information revolution,Technologe in Society2000,22:221-235. 